\title{
試料の準備方法の違いが粘性土のせん断特性に及ぼす影響 \\ Influence of Preparation Methods on Shear Characteristics of Cohesive Soils
}

\author{
亀 井 健 史* 佐 野 博 昭** \\ Takeshi KAMEI Hiroaki SANO
}

\begin{abstract}
In order to investigate the influence of preparation methods on shear characteristics of cohesive soils, direct shear tests have been performed on undisturbed and remoulded cohesive soils from Tokyo Bay.

The test result that the shearing strength of undisturbed samples turned out to be larger than that of remoulded samples. This difference may be attributed to the fact that the undisturbed samples have a natural soil structure of the soil remained unchanged. Engineering implication of the test results was turned out in making stability analysis of ground.
\end{abstract}

キーワード: 粘性土, 圧密非排水せん断, 直接せん断試験, 安定解析, せん断強さ, 試験方法

\section{1.まえがき}

海底地盤に生じる斜面崩壊としては，港湾工事におけ る掘削や載荷等の人工的な要因による崩壊と地震や重力 等に起因する崩壊が挙げられる1)。これらの斜面崩壊に 対して，適切な防止対策工法の選択およびその評価を行 うためには斜面の安定性を定量的に把握する必要がある。 現在, 一般的に用いられている斜面の安定解析手法と しては Bishop－法, Janbu一法および Morgenstern一法 等が挙げられるが,これらの手法で得られる安全率は, 解 析上必要となる土のせん断強さによって大きく変動する。 原位置における土のせん断強さを室内で評価する場合, 一般に，原位置より採取した乱さない試料あるいは同試 料の練返し再圧密試料に対して，一軸圧縮試験，三軸圧 縮試験および一面せん断試験等の各種室内試験が行われ ている。

しかしながら, 乱さない試料と練返し再圧密試料の強 度・変形特性は, 通常, 試験方法の違いによらず異なる ことが指摘されている2。。の原因として, 原位置におけ る土要素が二次圧密やセメンテーション等の年代効果の 影響を受けていることが指摘されている3)。

年代効果を受けた粘土のせん断強さを決定する方法と して, Bjerrum ${ }^{4)}$ は, 原位置での応力状態を再現すること が有効であると報告している。また，半沢(5) は，Bjerrum の手法をさらに拡張した修正Bjerrum法を提案している。 これに対し，Ladd and Foott ${ }^{6)}$ は，高位の構造を有す るクイッククレーや自然に固結した粘土を除きこれら

* 基礎地盤コンサルタンツ(侏) 地盤物性室

** 石川工業高等専門学校 土木工学科
の手法を一般に用いるべきではないと指摘しており，こ の点については, Bjerrum, 半沢の研究例とは必ずしも一 致しておらず，不明な点が多い。このことは，乱さない試 料を用いる場合, 試料の総量が不足していたり不均一で あったりするために, 年代効果を受けた地盤の強度・変形特 性が十分に解明されるに至っていないためと考えられる。

このため，原位置における土要素が過去に受けた年代 効果の影響を練返し再圧密試料を用いて，室内で再現す ることが可能となるならば，原位置における土の強度・ 変形特性に関する評価を容易に行うことができるように なるものと考えられる。

一方, 土田7) は, 上記に示した既往の研究成果をふまえ て, 乱さない試料と練返し再圧密試料に対して行った標 準圧密試験の結果より，正規圧密領域における試料の圧 縮性の変化を示す圧縮指数比が年代効果の影響を定量的 に表わす指標として有効であることを報告している。

従来，年代効果の影響を室内で再現する場合，長期間 圧密8) および化学的添加物の混合9,10) 等の方法が用いら れてきた。また，近年では，スラリー状の試料を高温で 再圧密する方法が頻繁に用いられている11,12)。

このうち, 長期間圧密による方法は, 年代効果の影響 を室内で再現する最も直接的な方法であるが，圧密に非 常に長期間を要する等の問題点が考えられる。また，化 学的添加物の混合や高温再圧密等の方法は, 練返し再圧 密試料に対して比較的容易に年代効果を与えることが可 能であるが, 練返し再圧密試料と原位置における土要素 の強度・変形特性に関する定量的な関係については, 不 明な点が多く, また, 添加物の種類や温度等の実験方法 についても明確に規定されていないものと考元られる。 
Table 1. Index properties of soil samples.

\begin{tabular}{|c|c|c|c|c|c|c|c|c|c|}
\hline Soil & $\begin{array}{c}\text { Depth } \\
(\mathrm{m})\end{array}$ & $\begin{array}{c}\rho_{\mathrm{S}} \\
\left(\mathrm{kN} / \mathrm{m}^{3}\right)\end{array}$ & $\begin{array}{c}w_{\mathrm{n}} \\
(\%)\end{array}$ & $\begin{array}{c}w_{\mathrm{L}} \\
(\%)\end{array}$ & $\begin{array}{c}w_{\mathrm{D}} \\
(x)\end{array}$ & $\mathrm{I}_{\mathrm{p}}$ & $\begin{array}{c}\text { Sand } \\
(x)\end{array}$ & $\begin{array}{c}\text { Silt } \\
(x)\end{array}$ & $\begin{array}{c}\text { Clay } \\
(x)\end{array}$ \\
\hline$M-1$ & $7 \sim 8$ & 26.7 & 71.6 & 55.3 & 29.1 & 26.2 & 30.8 & 40.3 & 28.9 \\
\hline$M-2$ & $13 \sim 14$ & 26.4 & 66.3 & 61.1 & 30.8 & 30.3 & 9.8 & 51.8 & 38.4 \\
\hline$M-3$ & $14 \sim 15$ & 26.3 & 64.0 & 56.9 & 28.8 & 28.1 & 10.0 & 48.0 & 42.0 \\
\hline$M-4$ & $16 \sim 17$ & 26.7 & 59.5 & 57.0 & 30.2 & 26.8 & 14.9 & 48.2 & 36.9 \\
\hline$M-5$ & $32 \sim 33$ & 26.3 & 40.5 & 45.2 & 26.3 & 18.9 & 3.1 & 59.7 & 37.2 \\
\hline$M-6$ & $33 \sim 34$ & 26.3 & 39.7 & 43.1 & 26.1 & 17.0 & 11.2 & 56.8 & 32.0 \\
\hline$M-7$ & $35 \sim 36$ & 26.0 & 40.9 & 49.9 & 29.9 & 20.0 & 0.0 & 37.3 & 62.7 \\
\hline
\end{tabular}

このことより，原位置における土のせん断強さを室内 で評価する場合, 乱さない試料を用いる以外には有効な 方法が見当たらないのが現状であると考えられる。

一方, 試料の含水比に着目すると, 原位置での有効土 被り圧を考慮した練返し再圧密試料の含水比が乱さない 試料の含水比より小さな值を示すにもかかわらず, 乱さ ない試料の一軸圧縮強さは，練返し再圧密試料の一軸圧 縮強さより大きくなることが報告されている13)。

また，土のせん断強さや力学的挙動を調べる目的では， 一般に，一軸圧縮試験や三軸圧縮試験等が行われており， 一面せん断試験を行う例は，比較的少ない。これは，在 来型一面せん断試験機がその構造上, 非排水条件でのせ ん断が困難であり, また，過剩間隙水圧の変化の測定が 不可能である等の理由によるものと考えられる。

三笠ら ${ }^{14)}$ は，これらの問題点を解決するために，改良 型一面せん断試験機を考案し,この試験機を用いて行っ た圧密定体積一面せん断試験と等方圧密および $K_{0}$ 圧密 三軸圧縮試験の結果より, 強度増加率 $c_{u} / p$ 值の試験方法 の違いによる差は，小さいと報告している。また，鈴木・ 吉田 ${ }^{15)}$ は, 粘土地盤の安定解析に用いるせん断強さの決 定方法を検討するために, $K_{0}$ 圧密三軸圧縮わよび伸張試 験, 圧密定体樻一面せん断試験を行い, 一面せん断試験 の有効性を指摘している。

このことは，良質でかつ均一な供試体を容易に準備す ることが可能な一面せん断試験が，土のせん断強さを評 価する上において有効な試験方法のひとつであることを 示しているものと考えられる ${ }^{16)} 。$

本研究は，上記の点に着目し，乱さない試料と同試料 の練返し再圧密試料に対して圧密定体積一面せん断試験 を行い, 乱さない試料と練返し再圧密試料のせん断特性 を定量的に把握することを試みた。さらに，上記の試験 から得られたせん断強さを用いて安定解析を行い, 試料 の準備方法の違いが安全率の值に及浔す影響についても 比較・検討を行った。

\section{2、試料および実験方法}

実験には，東京湾において (1) 深度 $7 \mathrm{~m} \sim 17 \mathrm{~m}$ より採 取した塑性指数 $I_{p}$ が 26〜30 と比較的 $I_{p}$ の高い 4 種類 の乱さない試料, (2) 深度 $32 \mathrm{~m} \sim 36 \mathrm{~m}$ より採取した $I_{p}$ が 17〜20 と比較的 $I_{p}$ の低い 3 種類の乱さない試料および (3)乱さない試料をそれぞれ練返して再圧密した試料を 用いた。試料の物理的特性, 粒径加積曲線を Table 1, Fig. 1 に示す。

表より， $I_{p}$ の比較的高い乱さない試料の含水比 $w_{n}$ 值 は，液性限界 $w_{L}$ 值より大きな值を示していることがわ かる。また，Fig. 2 に示す塑性図において全試料とも A 線上にほほ位置している。

乱さない試料は，採取後パラフィンワックスにより密 封保存したものを用いた。乱さない試料が原位置におい て受けたと考えられる応力履歴を考虑した場合，東京湾 の地質学的堆積環境より判断して，土被り圧が除去され た可能性は少なく ${ }^{5}$, このため, 今回の実験に用いた 7 種 類の乱さない試料は，正規圧密 aged 粘土 ${ }^{4)}$ に分類され るものと考えられる。

また，練返し再圧密試料の作成は，乱さない試料に液 性限界の 1.3 倍程度の含水比になるように脱気蒸留水を

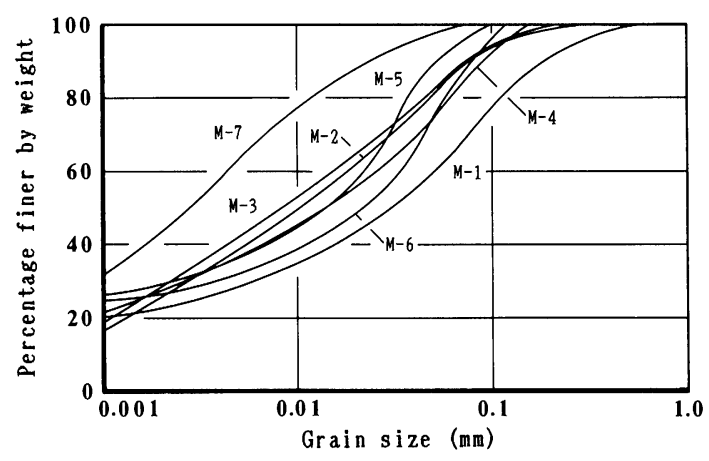

Fig. 1 Grain size distribution curves of samples. 


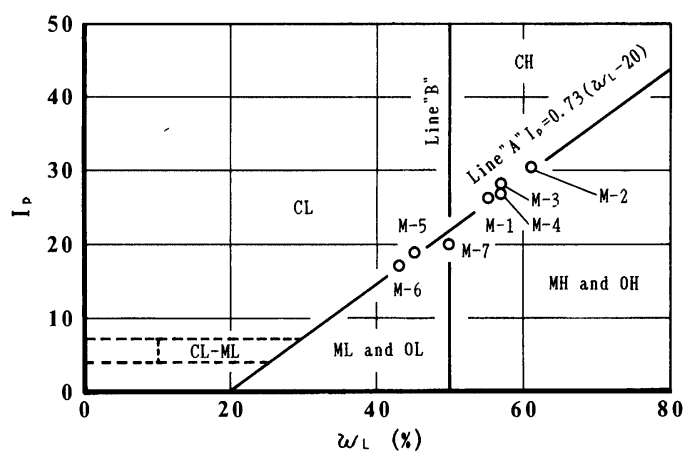

Fig. 2 Consistency characteristics of samples on plasticity chart.

加え, ミキサー内で 1 時間程度十分に練返してスラリー 状にした後, 直径 $10 \mathrm{~cm}$, 高さ $12.5 \mathrm{~cm}$ の予備圧密モー ルドに入れて一次元的に行った。予備圧密時の圧密圧力 は, 原位置において土要素が受けていた有効土被り圧と その自然含水比を考慮して, 以下に示す 2 種類を用いた。 なお, 予備圧密時の圧密時間は, 試料の一次圧密終了時 間を考慮して約 1 週間とした。

(1) 原位置での有効土被り圧 $p_{0}$ と同じ圧密圧力

(2) 練返し再圧密試料の含水比が乱さない試料の含水 比 $w_{n}$ とほほ同じとなる圧密圧力

なお，本文では，(1)により作成した練返し再圧密試料 を原位置での有効土被り圧考慮, (2)により作成した練返 し再圧密試料を自然含水比考慮とそれぞれ区別する。

得られた乱さない試料と練返し再圧密試料の含水比の 比較を Table 2 に示す。表より，各試料とも原位置での 有効土被り圧を考慮した練返し再圧密試料の含水比 $w_{r p}$ 值は, 乱さない試料の含水比 $w_{n}$ 值より小さな值を示し, その差は, $I_{p}$ の高い試料では $10 \% \sim 20 \%, I_{p}$ の低い試料 では $5 \%$ 10\%となり，Ip の高い試料ほどその差が大き くなっている。また, 自然含水比を考慮した練返し再圧 密試料の含水比 $w_{r n}$ 值は, $w_{n}$ 值とほほ同程度である。な お, $I_{p}$ が高い試料 $(\mathrm{M}-1 \sim \mathrm{M}-4)$ においては, 前述し たように $w_{n}$ 值が $w_{L}$ 值より大きな值となっているため, 自然含水比を考慮した練返し再圧密試料の供試体の作成 が不可能であった。実験に用いた供試体の形状は, 直径 $6 \mathrm{~cm}$, 高さ $2 \mathrm{~cm}$ である。

試験機は, 改良型一面せん断試験機を用い, せん断中 に供試体の体積を一定に保つ圧密定体積一面せん断試験 （一面 CU 試験）を行った。

年代効果の影響を受けた粘土は, 通常, 正規圧密地盤 において圧密降伏応力 $p_{c}$ が原位置での有効土被り圧 $p_{0}$ より大きな值を示す擬似過圧密状態となっていると言わ れている。今回の実験に用いた乱さない試料に対して 行った標準圧密試験の結果より, $I_{p}$ の高い試料 $(\mathrm{M}-$
Table 2. Summary of water content obtained by different preparation methods.

\begin{tabular}{|c|c|c|c|c|c|}
\hline Soi 1 & Depth $(m)$ & $I_{D}$ & $w_{n}(\%)$ & $w_{r_{p}}(x)$ & $w_{r_{n}}(x)$ \\
\hline$M-1$ & $7 \sim 8$ & 26.2 & 71.6 & 56.3 & - \\
\hline$M-2$ & $13 \sim 14$ & 30.3 & 66.3 & 50.6 & - \\
\hline$M-3$ & $14 \sim 15$ & 28.1 & 64.0 & 45.4 & - \\
\hline$M-4$ & $16 \sim 17$ & 26.8 & 59.5 & 49.0 & - \\
\hline \hline$M-5$ & $32 \sim 33$ & 18.9 & 40.5 & 35.3 & 36.8 \\
\hline$M-6$ & $33 \sim 34$ & 17.0 & 39.7 & 29.0 & 38.0 \\
\hline$M-7$ & $35 \sim 36$ & 20.0 & 40.9 & 36.1 & 39.7 \\
\hline
\end{tabular}

$w_{n}:$ Water content of undisturbed sample $w_{r p}:$ Water content of remoulded sample considered po $w_{r n}$ : Water content of remoulded sample considered $w_{n}$

1〜M-4)の $p_{c}$ 値は, $130 \mathrm{kPa} \sim 180 \mathrm{kPa}, I_{p}$ の低い試料 $(\mathrm{M}-5 \sim \mathrm{M}-7)$ の $p_{c}$ 値は, $420 \mathrm{kPa} \sim 480 \mathrm{kPa}$ となり, 原位置での有効土被り圧 $p_{0}$ 値の 1.5 倍〜2 倍となった。 この点を考慮して, 圧密圧力 $\sigma_{n c}{ }^{\prime}$ は, $I_{p}$ の高い試料の場 合, $196 \mathrm{kPa}$ および $392 \mathrm{kPa}, I_{p}$ の低い試料の場合, 490 $\mathrm{kPa}$ および $686 \mathrm{kPa}$ のそれぞれ 2 種類とし， 24 時間圧 密を行った。また, せん断速度は, 土質試験法 ${ }^{16)}$ を参考 にして, $0.5 \mathrm{~mm} / \mathrm{min}$ とした。

\section{3 、実験結果および考察}

得られた実験結果より, $I_{p}$ の高い試料 $(\mathrm{M}-1 \sim \mathrm{M}-4)$ および $I_{p}$ の低い試料 $(\mathrm{M}-5 \sim \mathrm{M}-7)$ のせん断特性は, それぞれほほ同様の挙動を示すことが認められた。この ため, 以下では, 高塑性土の場合, $\mathrm{M}-3$ 試料, 低塑性土 の場合, M-7 試料の代表的な結果について述べる。

Fig. 3 は, $\mathrm{M}-3\left(I_{p}=28.1\right)$ の試料を用いた場合, Fig. 4 は, M-7 $\left(I_{p}=20.0\right)$ の試料を用いた場合の乱 さない試料と原位置での有効土被り圧および自然含水比 を考慮した練返し再圧密試料のせん断応力 $\tau$ とせん断 変位 $D$ の関係をそれぞれ比較している。なお, $\mathrm{M}-3$ の 試料においては, 自然含水比を考慮した練返し再圧密試 料の供試体の作成が不可能であった。

一方, 再圧密終了時の含水比に着目すると, 練返し再 圧密試料においては, 各条件ともほほ同一の含水比を示 したが, 乱さない試料では, 練返し再圧密試料より $5 \%$ 〜 10\%大きな值を示した。

図より, $\mathrm{M}-3, \mathrm{M}-7$ 両試料ともせん断開始後, せん 断変位 $D$ の増加とともに $\tau$ は増加し, $\tau$ が最大となるせ ん断変位 $D_{f}$ は, $2 \mathrm{~mm}$ 以内となった。通常, 一軸圧縮試 験および三軸圧縮試験等を行った場合, 乱さない試料と 練返し再圧密試料の破壊時の軸ひずみ $\left(\varepsilon_{a}\right)_{f}$ 值を比較す ると, 両者の值は大きく異なり, 練返し再圧密試料の 


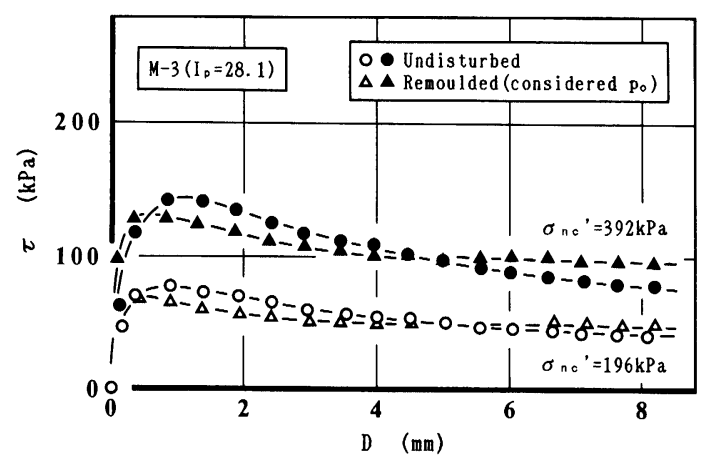

Fig. 3 Typical $\tau-D$ behaviour of $\mathrm{M}-3$ : undisturbed and remoulded samples.

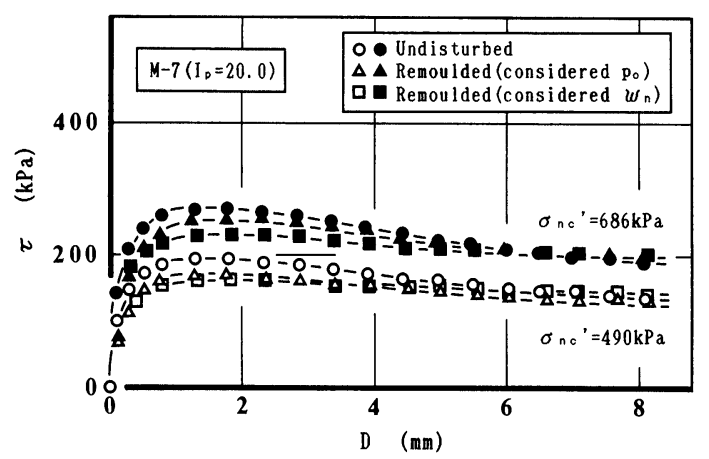

Fig. 4 Typical $\tau-D$ behaviour of $\mathrm{M}-7$ : undisturbed and remoulded samples.

$\left(\varepsilon_{a}\right)_{f}$ 值は, 乱さない試料のそれより大きくなることが報 告されている7。しかしながら, 今回行った一面せん断試 験ではそのような傾向は認められなかった。

一方， M-3 および $\mathrm{M}-7$ の乱さない試料と原位置で の有効土被り圧を考慮した練返し再圧密試料の最大せん 断強さ $\tau_{f}$ 值を比較すると, $\mathrm{M}-3$ の試料の場合, $w_{r p}$ 值 が $w_{n}$ 值より $20 \%$ 程度, $\mathrm{M}-7$ の試料の場合 $5 \%$ 程度それ ぞれ小さいにもかかわらず, 乱さない試料の $\tau_{f}$ 值が練返し 再圧密試料の $\tau_{f}$ 值より $10 \%$ 程度大きな值を示している。

亀井ら ${ }^{13)}$ は, 試料の準備方法の違いが粘性土の一軸圧 縮試験結果に及ほすす影響を検討するために，東京湾より 採取した海成粘性土 $\left(I_{p} \fallingdotseq 30\right)$ に対して一軸圧縮試験を 行った結果, 予備圧密時において原位置での有効土被り 圧を考慮した練返し再圧密試料の含水比が乱さない試料 の含水比より $5 \%$ 程度小さいにもかかわらず, 乱さない 試料の一軸圧縮強さ $q_{u}$ 值が練返し再圧密試料の $q_{u}$ 值 より 13\%〜20\%大きくなったと報告している。

一軸圧縮試験と一面せん断試験のように試験方法に違 いはあるものの, 今回行った一面せん断試験においても ほほ同様の傾向が得られた。

以上のことから, 乱さない試料は, 原位置での有効土
被り圧により, 二次圧密やセメンテーション等の年代効 果の影響を受けているため，その土構造を破壊された練 返し再圧密試料の含水比が乱さない試料の含水比より小 さいにもかかわらず，乱さない試料が練返し再圧密試料 より大きなせん断強さを示したものと考えられる。

さらに，M-7 の乱さない試料と自然含水比を考虑し た練返し再圧密試料の $\tau_{f}$ 值を比較すると, 乱さない試料 の $\tau_{f}$ 值が練返し再圧密試料の $\tau_{f}$ 值より $15 \%$ 程度大き くなり, 両試料の $\tau_{f}$ 值の差は, 乱さない試料と原位置て の有効土被り圧を考虑した練返し再圧密試料の場合と比 較して，さらに大きな值となった。

このことは，乱さない試料と自然含水比を考虑した練 返し再圧密試料の供試体の含水比がほほ同程度であるこ とから判断して, 両試料の $\tau_{f}$ 值の差は, 二次圧密やセメ ンテーション等の年代効果の影響を示しているものと考 えられる。

また, $\tau$ が最大值を示した後, せん断変位 $D$ の増加に よる $\tau$ の低下割合は， $I_{p}$ の大きさによらず，乱さない試 料が練返し再圧密試料より大きく, $\tau$ は, せん断変位 $D$ が $4 \mathrm{~mm}$ 程度で両試料ともほほ一定值に達している。

Fig. 5，6 は，M-3 および M-7 の試料を用いた場合 の代表的な有効応力径路を示したものである。図より，

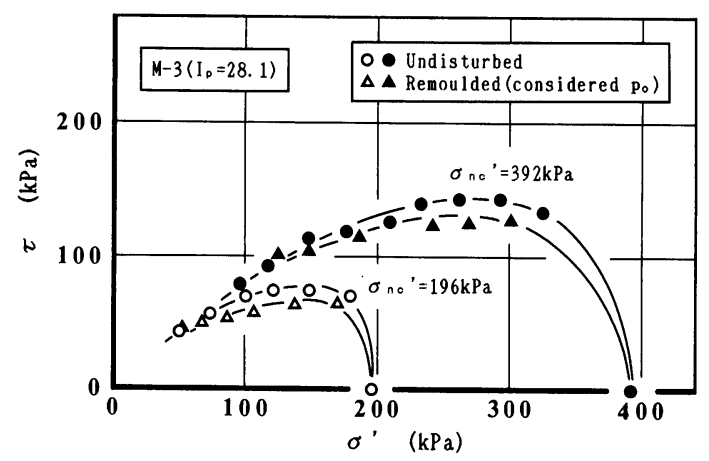

Fig. 5 Typical effective stress paths of $\mathrm{M}-3$ : undisturbed and remoulded samples.

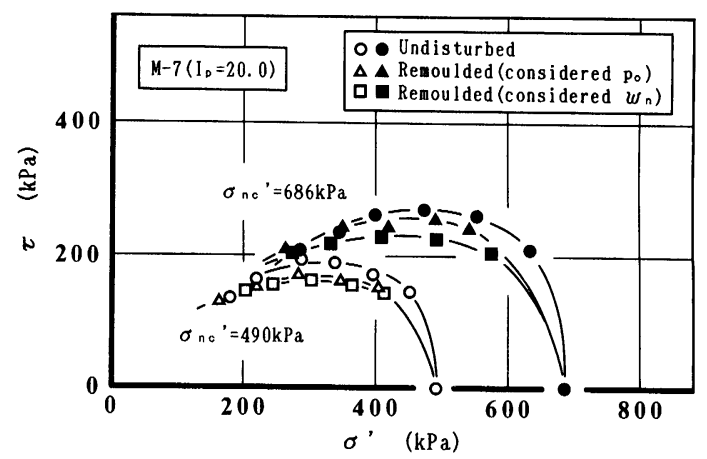

Fig. 6 Typical effective stress paths of $M-7$ : undisturbed and remoulded samples. 
$\mathrm{M}-3, \mathrm{M}-7$ 両試料ともせん断開始後, 有効垂直応力 $\sigma$, の減少に伴いせん断応力 $\tau$ は, 増加するが, $\tau$ が最大值を 示した後, $\tau$ は, $\sigma$ 'の減少に伴って減少し, 最終的にはあ る一定の包絡線上にそれぞれ漸近していることがわかる。 ここで, 有効応力径路の形状を比較すると, 両試料と も圧密圧力 $\sigma_{n c}$ 'の大きさによらず，ほぼ相似形の挙動を 示していることがわかる。また， $\mathrm{M}-7$ の試料において， 原位置での有効土被り圧を考慮した練返し再圧密試料と 自然含水比を考慮した練返し再圧密試料の有効応力径路 の形状を比較すると, $\sigma_{n c}{ }^{\prime}=490 \mathrm{kPa}$ の場合, 予備圧密時 における圧密圧力の大きさの影響は僅かであるが， $\sigma_{n c}$ $=686 \mathrm{kPa}$ においてはその影響が認められる。このこと は, 予備圧密時において原位置での有効土被り圧を考慮 した練返し再圧密試料が, 自然含水比を考慮した練返し 再圧密試料より再圧密時の二次圧密時間が長くなり, そ の結果，粘土粒子によって構成されている骨格構造がよ り安定した状態になるためと考えられる。

$\mathrm{M}-3$ および $\mathrm{M}-7$ の試料を用いた場合の最大せん断 強さ $\tau_{f}$ と垂直応力 $\sigma$ の関係を示したのが Fig. 7,8 であ り, 乱さない試料と原位置での有効土被り圧および自然 含水比を考慮した練返し再圧密試料の強度増加率 $c_{u} / p$ 值の比較を行ったものである。また, Table 3 は, 今回

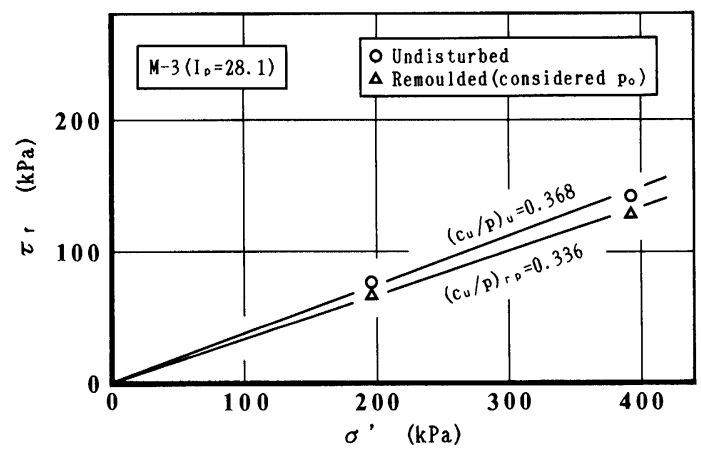

Fig. 7 Relationship between $\tau_{f}$ and $\sigma^{\prime}$ of $\mathrm{M}-3$ : undisturbed and remoulded samples.

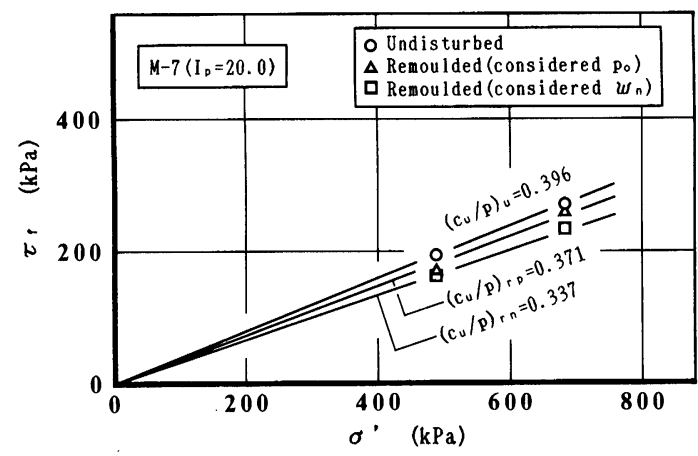

Fig. 8 Relationship between $\tau_{f}$ and $\sigma^{\prime}$ of $\mathrm{M}-7$ : undisturbed and remoulded samples.
Table 3. Summary of $c_{u} / p$ value obtained by different preparation methods.

\begin{tabular}{|c|c|c|c|c|c|}
\hline Soi 1 & Depth $(\mathrm{m})$ & $\mathrm{I}_{\mathrm{D}}$ & $\left(\mathrm{c}_{u} / \mathrm{p}\right)_{u}$ & $\left(\mathrm{c}_{u} / \mathrm{p}\right)_{\mathrm{rD}}$ & $\left(\mathrm{c}_{u} / \mathrm{p}\right)_{\mathrm{rn}}$ \\
\hline$M-1$ & $7 \sim 8$ & 26.2 & 0.367 & 0.392 & - \\
\hline$M-2$ & $13 \sim 14$ & 30.3 & 0.371 & 0.354 & - \\
\hline$M-3$ & $14 \sim 15$ & 28.1 & 0.368 & 0.336 & - \\
\hline$M-4$ & $16 \sim 17$ & 26.8 & 0.373 & 0.366 & - \\
\hline \hline$M-5$ & $32 \sim 33$ & 18.9 & 0.350 & 0.313 & 0.309 \\
\hline$M-6$ & $33 \sim 34$ & 17.0 & 0.387 & 0.363 & 0.340 \\
\hline$M-7$ & $35 \sim 36$ & 20.0 & 0.396 & 0.371 & 0.337 \\
\hline
\end{tabular}

$\left(c_{u} / p\right)_{u}: c_{u} / p$ value obtained using undisturbed sample $\left(c_{u} / p\right)_{r}: c_{u} / p$ value obtained using remoulded sample considered po

$\left(c_{u} / p\right)_{r n}: c_{u} / p$ value obtained using remoulded sample considered $w_{n}$

の実験に用いた 7 種類の試料に対する乱さない試料の強 度増加率 $\left(c_{u} / p\right)_{u}$ 值, 原位置での有効土被り圧を考慮し た練返し再圧密試料の強度増加率 $\left(c_{u} / p\right)_{r p}$ 值および自然 含水比を考慮した練返し再圧密試料の強度增加率 $\left(c_{u} / p\right)_{r n}$ 値をそれぞれ示している。

表より, 深度 $13 \mathrm{~m} \sim 17 \mathrm{~m}$ より採取した比較的 $I_{p}$ が高 い試料 $(\mathrm{M}-1 \sim \mathrm{M}-4)$ の $c_{u} / p$ 値に着目すると, $\left(c_{u} / p\right)_{u}$ 值が $\left(c_{u} / p\right)_{r p}$ 值より $5 \%$ ～10\%大きな值を示しているこ とがわかる。しかしながら, 深度 $7 \mathrm{~m} \sim 8 \mathrm{~m}$ と比較的浅い 深度より採取した $\mathrm{M}-1$ の試料では逆の傾向となってい る。このことは, $\mathrm{M}-1$ の試料が $31 \%$ の砂分を含んでい ることから，試料採取に伴う機械的な乱れや応力解放を 他の試料と比較してかなり受けていることおよび土要素 が末圧密の状態であること等が考えられる。よって, 砂 分の多い粘性土は, 試料採取に伴う乱れの影響を受け易 いため, 高品質な乱さない試料を採取するためには十分 に注意する必要があるものと考えられる。

一方, 深度 $32 \mathrm{~m} \sim 36 \mathrm{~m}$ より採取した $I_{p}$ が比較的低い 試料 $(\mathrm{M}-5 \sim \mathrm{M}-7)$ の強度増加率 $c_{u} / p$ 值に着目すると, $\left(c_{u} / p\right)_{u}$ 值が $\left(c_{u} / p\right)_{r p}$ 值より $5 \%$ ～10\%， $\left(c_{u} / p\right)_{r n}$ 值より 10\%～15\%大きな値を示している。

半沢 ${ }^{5)}$ は, 乱さない試料を原位置での有効土被り圧 $p_{0}$ 以上の圧密圧力で圧密した場合, 間隙比の減少は年代効 果によって形成された土構造を破壊するため，せん断強 さの増加には寄与せず, 圧密圧力が圧密降伏応力 $p_{c}$ に達 した時点で年代効果により形成されたせん断強さは, 完 全に消失し, 正規圧密 young 粘土 ${ }^{4)}$ となると報告してい る。

しかしながら，嘉門・長尾9)は，人工的にセメンテー ションを与えた粘土の三軸圧縮試験結果より，非排水せ ん断強さは，過圧密領域においても圧密圧力の増加に伴 
う間隙比の減少により增大していることを示し，半沢の 結果とは異なる結果を報告している。また, 圧密降伏応 力 $p_{c}$ の 1 倍〜3 倍の圧密圧力を用いた本研究において は, 圧密圧力の大きさによらず，乱さない試料のせん断 強さは, 練返し再圧密試料のせん断強さより大きな值を 示している。このことは, 圧密降伏応力以上の圧密圧力 で圧密された乱さない試料においても, 年代効果により 形成された土構造は, ある程度維持されているものと考 えられ, 既往の研究例(5) とは異なる結果が得られた。いず れにしても, 原位置における土のせん断強さを室内で評 価することは, 工学的に重要な問題であることを示唆し ている。

以上のことょり，原位置での有効土被り圧を考慮した 練返し再圧密試料より得られたせん断強さを実地盤に適 用することは, 実地盤のせん断強さを過小評価している 可能性があることおよび自然含水比を考慮した練返し再 圧密試料のせん断強さは, 原位置での有効土被り圧を考 虑した練返し再圧密試料のせん断強さよりさらに小さく なることが明らかとなった。このことから，乱さない試 料と自然含水比を考慮した練返し再圧密試料のせん断強 さの差が年代効果の影響を示しているものと考えられる。 上記の実験から得られたせん断強さの工学的解釈とし て, 得られた結果を用いて安定解析を行い, 安全率 $F_{s}$ が 試料の準備方法の違いによりどの程度変化するのかを検 討する。ここでは，Fig. 9 に示すような等分布荷重を受 ける連続基礎 ( $B / L=0)$ の断面 ${ }^{17), 18)}$ を安定解析対象断 面とし, 今回の実験から得られたせん断強さを用い, 中 瀬 ${ }^{17)}$ により提案された方法で安定解析を行った。なお， 地下水位は, 地表面に一致しているものとする。また, 支持地盤の非排水せん断強さ $c_{u}$ は, 深さに対して直線 的に増加するものと仮定し, $c_{u}=c_{0}+k \cdot z,(\phi=0) に$ より表わす。ここで， $c_{0}$ は地表面での非排水せん断強さ ( $c_{0}=10 \mathrm{kPa}$ と仮定), $k$ は土の非排水せん断強さの深 さに対する堌加割合を示すものであり, $k$ は土の水中単 位体積重量 $\gamma^{\prime}$ と強度増加率 $c_{u} / p$ 值の積に等しい。

Table 4 は, 実験に用いた 7 種類の試料に対し, 試料 の準備方法の違いにより得られたせん断強さを用いて安 定解析を行った場合の安全率 $F_{s}$ の值をまとめたもので ある。なお, $\left(F_{s}\right)_{u}$ 值は乱さない試料, $\left(F_{s}\right)_{r p}$ 值は原位置 での有効土被り圧を考虑した練返し再圧密試料および $\left(F_{s}\right)_{m}$ 值は自然含水比を考慮した練返し再圧密試料のせ ん断強さをそれぞれ用いることにより得られた安全率の 値を示している。

表より, $\left(F_{s}\right)_{u}$ 值は, $\left(F_{s}\right)_{r p}$ 值より $5 \%$ 程度, $\left(F_{s}\right)_{r n}$ 值 より $10 \%$ 程度大きくなるという結果が得られた。このこ とは, 練返し再圧密試料から得られたせん断強さを用い て実地盤の安定解析を行うことは, 実地盤の安定性を過

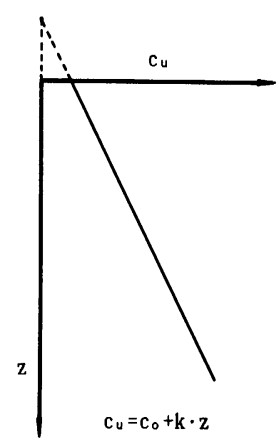

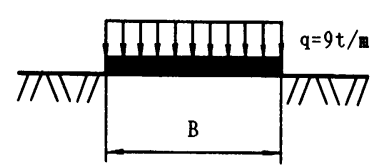

Length of footing: $\mathrm{L}$
Fig. 9 The case considered in the present analysis ${ }^{17), 18)}$.

Table 4. The minimum factor of safety for continuous footing obtained by the slip circle method.

\begin{tabular}{|c|c|c|c|c|c|}
\hline Soil & Depth (m) & $I_{D}$ & $\left(F_{s}\right)_{u}$ & $\left(F_{s}\right)_{i d}$ & $\left(F_{s}\right)_{r n}$ \\
\hline$M-1$ & $7 \sim 8$ & 26.2 & 1.27 & 1.31 & - \\
\hline$M-2$ & $13 \sim 14$ & 30.3 & 1.28 & 1.25 & - \\
\hline$M-3$ & $14 \sim 15$ & 28.1 & 1. 27 & 1.22 & - \\
\hline$M-4$ & $16 \sim 17$ & 26.8 & 1. 28 & 1. 27 & - \\
\hline$M-5$ & $32 \sim 33$ & 18.9 & 1. 24 & 1.18 & 1.18 \\
\hline$M-6$ & $33 \sim 34$ & 17.0 & 1.30 & 1.27 & 1.23 \\
\hline$M-7$ & $35 \sim 36$ & 20.0 & 1. 32 & 1.28 & 1.22 \\
\hline
\end{tabular}

$\left(F_{s}\right)_{u}$ :Factor of safety obtained using undisturbed sample

$\left(F_{s}\right)_{r D}:$ Factor of safety obtained using remoulded sample considered po

$\left(F_{s}\right)_{r_{n}}:$ Factor of safety obtained using remoulded sample considered $w_{n}$

小評価している可能性があることを示唆している。また， 年代効果が実地盤の安全率に及ほす影響は, $10 \%$ 程度と なる。

\section{4. 結 論}

本研究では, 乱さない試料と練返し再圧密試料のせん 断特性を定量的に把握するために, $I_{p}$ の異なる 7 種類の 乱さない試料および乱さない試料を 2 種類の予備圧密圧 カにより, 練返し再圧密した試料に対して圧密定体積一 面せん断試験を行った。

以下に, 本研究により得られた主要な結果を列挙する。

（1）予備圧密時において原位置での有効土被り圧を考 慮した練返し再圧密試料の含水比 $w_{r p}$ 值は, 乱さない試 料の含水比 $w_{n}$ 値と比較して, $5 \%$ ～20\%小さいにもかか わらず, 最大せん断強さ $\tau_{f}$ 值は, 乱さない試料が原位置 での有効土被り圧を考慮した練返し再圧密試料より $5 \%$ 〜 $10 \%$ 大きな值となる。

（2）乱さない試料と予備圧密時において自然含水比を 考慮した練返し再圧密試料の最大せん断強さ $\tau_{s}$ 值は, 両 
試料の供試体の含水比がほほ同じであるにもかかわらず, 乱さない試料が自然含水比を考慮した練返し再圧密試料 より $10 \%$ 15\%大きな值となる。

（3）乱さない試料と練返し再圧密試料の最大せん断強 さ $\tau_{\mathrm{f}}$ 值は, 乱さない試料が練返し再圧密試料より $5 \%$ 〜 $15 \%$ 大きな值を示すことが明らかとなった。このこと より, 乱さない試料が有していると考えられる年代効果 の影響をせん断特性の面からある程度定量的に示した。

（4）予備圧密時において原位置での有効土被り圧を考 慮した練返し再圧密試料と自然含水比を考慮した練返し 再圧密試料を比較すると, 予備圧密時に扔ける圧密圧力 の大きさの違いは, 再圧密終了時のせん断特性に僅かに 影響を及汸す。

（5）乱さない試料の最大せん断強さ $\tau_{f}$ 值は, 練返し再 圧密試料より大きな值を示し, 圧密降伏応力 $p_{c}$ 以上の圧 密圧力 $\sigma_{n c}{ }^{\prime}$ 下で圧密された試料颃いても, 年代効果に より形成された土構造は, ある程度維持されているもの と考えられる。

（6）乱さない試料から得られたせん断強さを用いて安 定解析を行うと, 練返し再圧密試料のせん断強さを用い た場合と比較して安全率 $F_{s}$ 值は, $5 \%$ 10\%大きな值と なる。このことは, 練返し再圧密試料から得られたせん 断強さを実地盤に適用すると, 実地盤の安定性を過小評 価している可能性があることを示唆している。また，年 代効果が実地盤の安全率 $F_{s}$ 值に及ほす影響は, $10 \%$ 程 度であるといえる。

以上のことより, 原位置において土要素が受けたと考 えられる年代効果の影響を定量的に把握することは, 実 地盤の安定性を評価する際の重要な要素であるといえる。

\section{謝 辞}

本研究を遂行するにあたり, 実験および結果の整理に ご協力いただいた石川工業高等専門学校卒業生東出洋和 (現, NTT (战), 與坂聡 (現, 山口大学) 両君に謝意を表 します。

\section{参考文献}

1）中瀬明男: 海洋土質, 技報堂, pp. 157 162，1984

2) Graham. J and Li, E. C. C.: Comparison of Natural and Remolded Plastic Clay, Proc. ASCE, Vol. 111, No. GT 7, pp. $865 \sim 881,1985$

3 ) 中瀬明男, 亀井健史: 日本近海における海底沖積粘土地 盤の工学的特性, 土木学会論文報告集, No. 338, pp. 217 224, 1983

4 ) Bjerrum, L.: Problems of Soil Mechanics and Construction on Soft Clays and Structurelly Unstable Soils (Collapsible, Expansive and Others), Proc. 8th ICSMFE, Vol. 3, pp. 111 159, 1973

5 ) Hanzawa, H.: Undrained Strength Characteristics of an Alluvial Marine Clay in the Tokyo Bay, Soils and Foundations, Vol. 19, No. 4, pp.69 84, 1979

6) Ladd, C. C. and Foott, R.: New Design Procedure for Stability of Soft Clays, Proc. ASCE, Vol. 100, No. GT 7, pp. 763〜786, 1974

7 ) 土田 孝: 三軸試験による自然粘性土地盤の強度決定法 に関する研究, 運輸省港湾技研資料, No. 688 , pp. 85〜115, 1990

8) Mitachi, T. and Fujiwara, Y.: Undrained Shear Behavior of Clays Undergoing Long-term Anisotropic Consolidation, Soils and Foundations, Vol. 27, No. 4, pp. $45 \sim 61,1987$

9 ) 嘉門雅史, 長尾 毅: 人工的にセメンテーション効果を 与えた粘性土の土質工学的特性について, 第 21 回土質工 学研究発表会講演集, pp. 389 390, 1986

10）嘉門雅史, 佐野郁雄, 陶 秀珍: 人工的に粒子間にセメン テーションを与えたカオリン粘土の物理化学的特性, 土 木学会第 42 回年次学術講演会講演概要集, pp. 302 303, 1987

11）土田 孝, 水上純一, 小林正樹, 平良 聡: 高温で再圧密 した海成粘土の力学特性, 第 23 回土質工学研究発表会講 演集, pp. $515 \sim 516,1988$

12）土田 孝, 小林正樹, 水上純一, 田中政典: 高温再圧密に よる海成粘土の年代効果の再現, 運輸省港湾技術研究所 報告, Vol. 28, No. 1, pp. 121 147, 1989

13）亀井健史, 中村嘉博, 常田亮: 不摫乱試料と練返し試料に おける供試体の寸法効果, 第 18 回土木学会関東支部技術 研究発表会講演概要集, pp. 160 161, 1991

14）三笠正人, 西垣好彦, 岡島洋一: 各種試験方法による $c_{u} / p$ 值の比較, 第 13 回土質工学研究発表会講演集, pp. 325 328, 1978

15）鈴木耕司, 吉田信行: 三軸および一面せん断試験による 地盤の力学特性の評価, 三軸試験方法に関するシンポジ ウム発表論文集, 土質工学会, pp. 231 236, 1991

16）土質工学会編: 土質試験法 [第 2 回改訂版], 1979

17） 中瀬明男: 粘性土地盤の支持力, 運輸省港湾技術研究所 報告, Vol. 5, No. $12,58 \mathrm{p}, 1966$

18) Kamei, T.: Effects of Undrained Shear Strength Anisotropy on Bearing Capacity Factor of Cohesive Soil Stratum, Tech. Rep. TUN., Vol. 8, pp. 207 215, 1986

(原稿受理日 平成 4 年 7 月 15 日) 
高速リングせん断試験機による土砂の運動時の内部摩擦角の測定

「地すべり」Vol. 29, No. 4 (通巻第 112 号) pp. 1 8, 1993 年（平成 5 年） 3 月

佐々 恭二, 福岡 浩

地すべり運動時に発揮される内部摩擦角は，通常のせん断試験で得られる内部摩擦角とは必ずしも同じではな いと思われる。そこで実際の地すべりの運動に刘応する速度でせん断抵抗を計測することを目的として, 表層崩 壊などを研究対象とした低圧用 $(39 \mathrm{kpa})$ の高速リングせん断試験機と地すべりを研究対象とした高圧用 $(390$

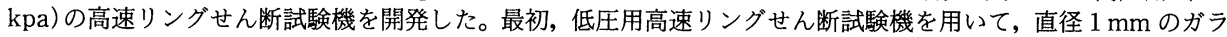
スビーズについて予備試験を行い，間隙流体の粘性抵抗は，表層崩壊に対応する $(10-40 \mathrm{kpa}$ 程度）低い垂直応 力のもとでも摩擦抵抗に比べて無視し得ることを確認したっついで, 高速高圧リングせん断試験機を用いて御岳 大崩壊や地附山地すべりの土など種々の土について $0.01 \mathrm{~cm} / \mathrm{sec}-100 \mathrm{~cm} / \mathrm{sec}$ のせん断速度で試験を行った。そ の結果, 得られた内部摩擦角は土によって挙動が異なり, せん断速度の增大により内部摩擦角が增大するもの, 逆に減少するもの, ほとんど変化しないものがあった。しかしその変化は一 -3.2 度から +3.7 度までの範囲にあ り，それほど大きなものではなかった。これらの内部摩擦角の变化の原因としては，せん断中の粒子の破砝によ る粒度分布と粒子形状の変化が考えられ，また，比較的粒径がそろっている材料では，粒子がせん断方向に配列 する影響があると思われた。

地すべり粘性土の一面せん断試験における破壊の伝播過程

「地すべり」Vol. 29, No. 4 (通巻第 112 号) pp. 9 17, 1993 年（平成 5 年） 3 月

金井 俊孝, 宮田雄一郎

地すべり粘土の定体積一面せん断試験を行い，供試体内部における破壊面の発達過程について，特に破壊の伝 播速度の観点から検討を加えた。試料には福島県与内烟地すべりから採取された粘土,カリオン HA, ベントナイ 卜を用意し, 直径 $6 \mathrm{~cm}$, 高さ $2 \mathrm{~cm}$ の円盤状共試体沉導電性塗料を塗布した 6 本の素麵マーカ一をせん断方向に 対して縦列に配置し, せん断した。せん断に先だってこれらの電極に $5 \mathrm{~V}$ の電圧を加え, 供試体の変形とせん断 によって電圧が逐次的に低下する状況を記録した。軟 X 線写真による観察から, これらの電極の切断プロセス は，供試体内部における破壊面の発達過程を的確に表現していることが明らかにされ，この電極の開発によって 破壊の伝播速度を議論することが可能になった。

モデル化された切土斜面の 3 次元安定解析と留意点

「地すべり」Vol. 29, No. 4 (通巻第 112 号) pp. 18〜24, 1993 年（平成 5 年） 3 月

鵜飼 恵三, 萩原 敏行, 井田 寿朗

モデル化された切土斜面に対して簡便分割法と弾塑性 FEM を用いた 3 次元安定解析を行い分割法を適用する

際の留意点を示し，現実に近いすべり面形状の予測には弾塑性 FEM を用いることが有効であることを指摘した。

\section{試料の準備方法の違いが粘性土のせん断特性に及ぼす影響}

「地すべり」Vol. 29, No. 4 (通巻第 112 号) pp. 25〜31，1993 年（平成 5 年）3月

重井 健史, 佐野 博昭

本研究では, 試料の準備方法の違いが粘性土のせん断特性に及ぽす影響を解明するために, 乱さない試料と練 返し再圧密試料に対して圧密定体積一面せん断試験を行った。

その結果, 乱さない試料と練返し再圧密試料の強度・変形特性は, 大きく異なることが定量的に示された。こ のことより, 練返し再圧密試料より得られたせん断強さを実地盤に適用した場合, 得られた解析結果は, 実地盤 の安定性を過小評価している可能性があることを示唆した。

地すべり地における表面歪の分布と変化

「地すべり」Vol. 29, No. 4 (通巻第 112 号) pp. 32〜36, 1993 年（平成 5 年） 3 月 川逶洋, 芝野 博文

小規模な地すべり地に, $2 \sim 4 \mathrm{~m}$ 間隔でほほ恪子状に配置した多数の測点の移動を, 光波セオドライトを用いて 繰り返し測量した。そのデー夕に二次元有限均一歪理論を適用して, 地表面の水平歪の分布と経時変化を求めた。 その結果, この方法は地すべりの局所的な変動の検出や予測のためのデー夕の取得に非常に有効であることが明 らかになった。

\section{地震とマスムーブメント}

「地すべり」Vol. 29, No. 4 (通巻第 112 号) pp. 37〜44, 1993 年（平成 5 年）3 月

中山 康

斜面の地震災害には, 岩石斜面の崩落と土砂斜面の滑動がある。前者は大きな加速度（すなわち力）で, 後者 は大きな仕事 work で発生する。斜面における加速度は震度 (最大加速度)で表現される。斜面滑動に関与する仕 事は, 震源のマグニチュード・震央距離で定まる到達エネルギーのうち波形に基づく何割かが転化したものであ る(波形が人工的な正弦曲線の場合, この割合は 0 となる)。

このため, 地震災害のハザードマップは 2 種類必要となり,「最大加速度」ならびに「マグニチュードと震央距 離」についての確率を知ることになる。 